\title{
A Case of Middle Ear Neuroendocrine Adenoma in a Patient with Hearing Loss and Facial Palsy
}

\author{
Woojoo Nam, Tae Hwan Kim, and Min-Beom Kim \\ Department of Otorhinolaryngology-Head and Neck Surgery, Kangbuk Samsung Hospital, \\ Sungkyunkwan University School of Medicine, Seoul, Korea
}

\section{난청과 안면마비를 주소로 내원한 중이의 신경내분비 선종 1예}

남우주 · 김태환 · 김민범

성균관대학교 의과대학 강북삼성병원 이비인후과학교실

\author{
Received June 4, 2017 \\ Revised July 31,2017 \\ Accepted August 11, 2017 \\ Address for correspondence \\ Min-Beom Kim, MD, PhD \\ Department of Otorhinolaryngology- \\ Head and Neck Surgery, \\ Kangbuk Samsung Hospital, \\ Sungkyunkwan University \\ School of Medicine, \\ 29 Saemunan-ro, Jongno-gu, \\ Seoul 03181, Korea \\ Tel +82-2-2001-2269 \\ Fax +82-2-2001-2412 \\ E-mail minbeom.kim@gmail.com
}

Middle ear adenoma is a very rare disease which is benign and originates from the middle ear mucosa. Patients of middle ear adenoma usually come to the clinic for unilateral hearing loss or tinnitus, but rarely for accompanied facial palsy. It is non-gender specific and occurs over a wide range of ages. The recurrence rate is known to be very low, but few authors argue that neuroendocrine adenoma should be considered as a low grade carcinoma due to some cases of recurrence. A 18 years-old male who had a left side facial palsy about 3 years ago but has currently improved as compared with the initial onset, visited our clinic for the left side hearing loss. Pure tone audiogram showed about $30 \mathrm{~dB}$ of conductive hearing loss and a pinkish polypoid mass involving the left tympanic membrane. We removed a tumor via transmastoid approach. The final diagnosis was middle ear adenoma with neuroendocrine differentiation. Neither signs of complication nor recurrence were observed after six months of the surgery.

Korean J Otorhinolaryngol-Head Neck Surg 2019;62(3):182-7

Key Words Middle ear adenoma - Middle ear tumor - Neuroendocrine differentiation.

\section{서 론}

중이의 선종은 매우 흔하지 않은 질환으로 1976년 Hyams 와 Michaels ${ }^{1}$ 에 의해 처음 발견되었다. 우리나라에서는 중이 의 선종을 1991년 Kwon 등'이 보고하였고 이후에도 몇 차례 보고된 바 있다. ${ }^{3)}$ 초기에는 신경내분비종양과 중이의 선종이 서로 다른 개념으로 사용되었으나 신경내분비종양이 전이가 매우 드물고 수술적 절제 후 재발이 흔하지 않는 등 양성의 행 동양식을 주로 보이는 연구결과로 인해 현재는 같은 개념으 로 보아야 한다는 보고도 있다. 1867년 Langhans에 의해 처 음 소화기의 칼시노이드종양이 보고된 이후 주로 폐와 소화기

This is an Open Access article distributed under the terms of the Creative Commons Attribution Non-Commercial License (http://creativecommons.org/licenses/by-nc/4.0) which permits unrestricted non-commercial use, distribution, and reproduction in any medium, provided the original work is properly cited.
에서 보고되고 있으나 두경부에서는 매우 드물게 보고되고 있으며 발병한다면 주로 후두에서 발병하며 중이에서는 특 히 더 드문 것으로 알려져 있다. ${ }^{4)}$ 정상 구조의 중이에서는 신 경내분비세포가 없으나 중이열(middle ear cleft)의 변형된 호흡기점막에서 기원한다는 보고도 있으며 염증 반응이 중이 의 점막을 섬모를 동반한 분비활동을 하는 주기둥세포와 입 방세포로 화생시키는 것으로 알려져 있다.,5)

환자들은 주로 병측의 난청을 호소하며 이통 및 이루, 재발 성 중이염으로 내원하였다. 양측으로 학계에 보고된 경우는 없 으며 매우 드물게 병측의 안면마비가 동반되는 경우도 있지만 신경내분비 선종에 대해 특이적으로 나타나는 증상은 없다. 종양은 대부분 고실에서 기원하며 드물게는 유양돌기동 혹은 이관까지 침범한다. 재발은 흔하지 않으며 수술적 절제만으로 충분한 것으로 보고되어 있다.7, 
저자들은 일측의 안면마비, 전음성 난청과 고막 내 종물로 내원한 중이의 신경내분비성 선종 1 예를 체험하였기에 이를 문 헌고찰과 함께 보고하는 바이다.

\section{증 례}

약 한 달 전부터 발생한 좌측의 일측성 난청을 주소로 18 세 남환이 내원하였다. 3년 전 갑자기 발생한 동측의 눈이 감 기지 않는 완전안면마비로 치료한 병력이 있으며, 이후 많이 호 전되었으나 현재도 좌측 안면마비가 House-Brackmann grade II로 남아 있었다. 이외의 특이 과거력 및 가족력은 없었으며 좌이의 난청 외의 어지럼증이나 이충만감, 이명은 없었다. 고

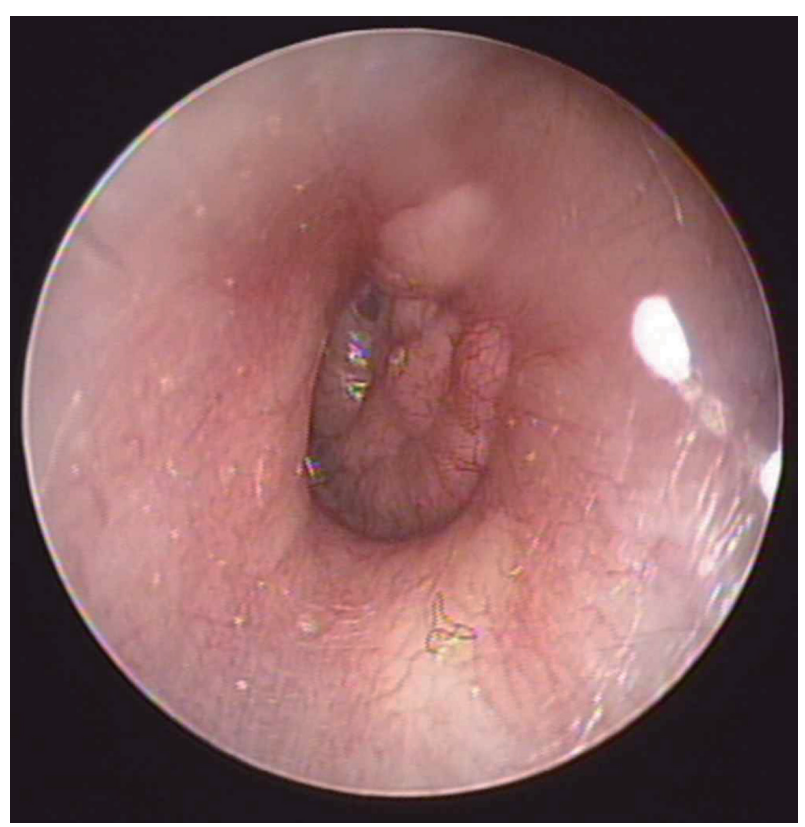

Fig. 1. An endoscopic exam of TM: preoperative tympanic membrane with soft, polypoid round lobulated mass involving whole TM while the external auditory canal is relatively intact. TM: tympanic membrane.
실내시경상 좌측 고막 전체를 침범하는 비교적 경계가 불분 명한 종물이 관찰되었으며 외이도를 침범하지는 않았다(Fig. 1). 순음청력검사에서 우측은 정상, 좌측 기도 $46.7 \mathrm{~dB}$, 골도 $17.5 \mathrm{~dB}$ 의 전음성 난청이 있었으며, 어음 명료도는 양이 모두 $100 \%$ 로 관찰되었다(Fig. 2). 측두골 전산화단층촬영에서 좌 측 고막부터 중고실, 상고실에 이르는 연조직 음영이 관찰되 었으며 좌측 유양동 전반에 함기화가 감소되어 있었다. 중이 강 내의 연조직 음영은 추골 전체 및 침골의 몸통 부분을 둘 러싸고 있었으나 이소골 자체의 미란 등은 뚜렷하게 관찰되 지 않았으며, 명확한 내이와 안면신경의 침범 역시 관찰되지 않았다(Fig. 3). 내이도 자기공명영상에서 T2 강조영상에서는

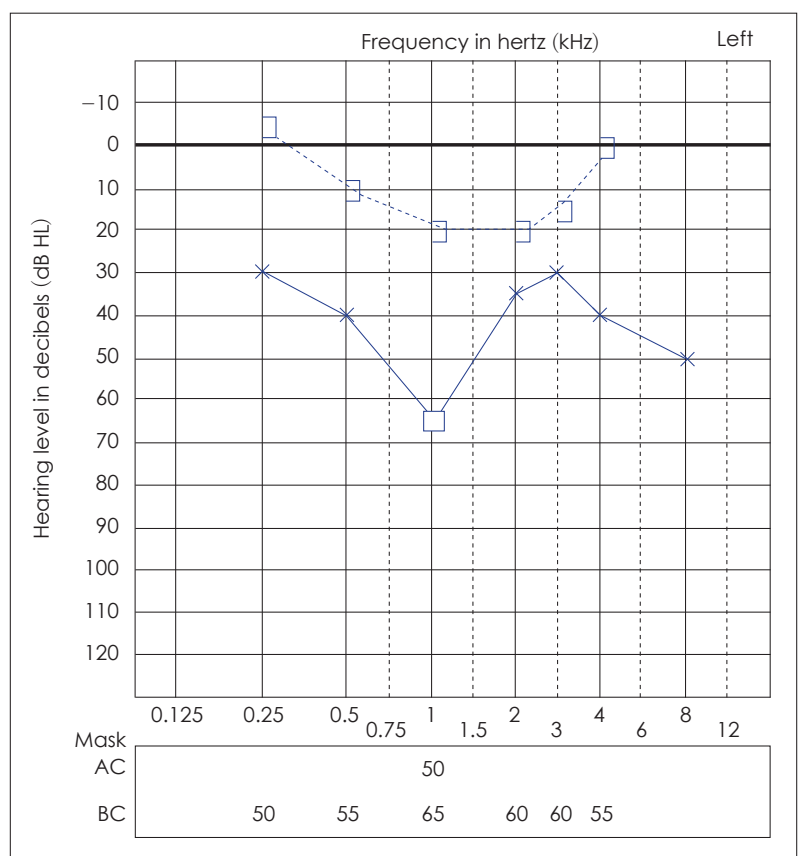

Fig. 2. The preoperative pure tone audiometry: left $46.7 \mathrm{~dB}$ in air conduction, 17.5 in bone conduction with air-bone gap of $29.2 \mathrm{~dB}$ which implies conductive hearing loss. AC: air conduction, BC: bone conduction.

Fig. 3. Temporal bone CT: coronal view $(A)$ and axial view (right) of left ear. The middle ear mass is involving malleus and incus, extending from mesotympanum to epitympanum (A). The mass involves tympanic membrane and malleus and incus in axial view (B), however the mass is not involving facial nerve.
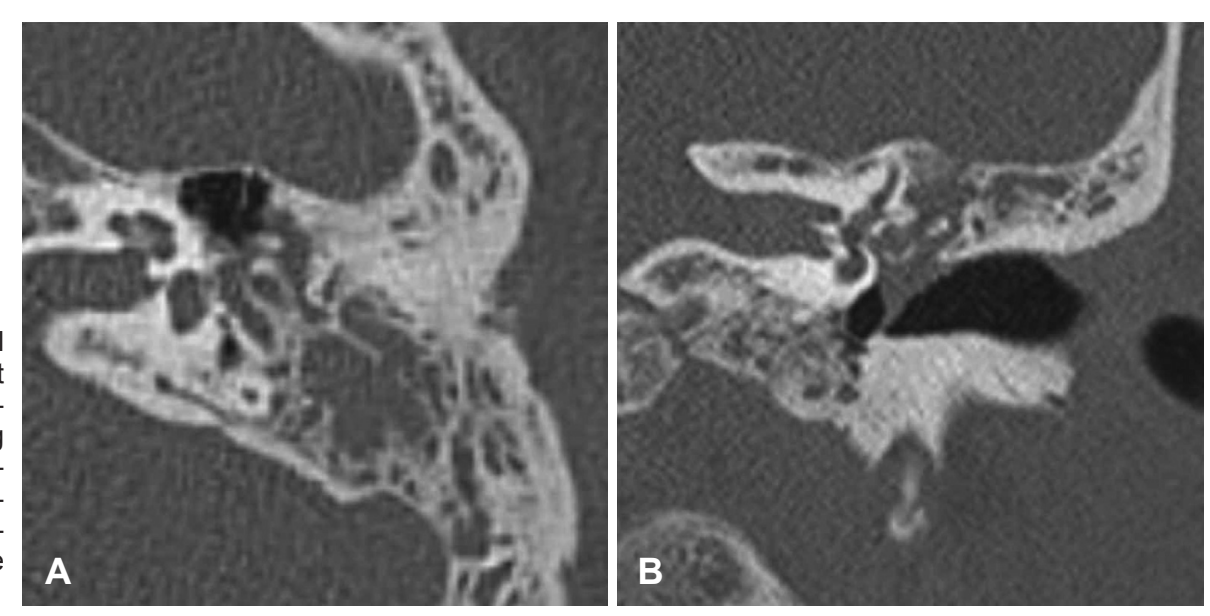

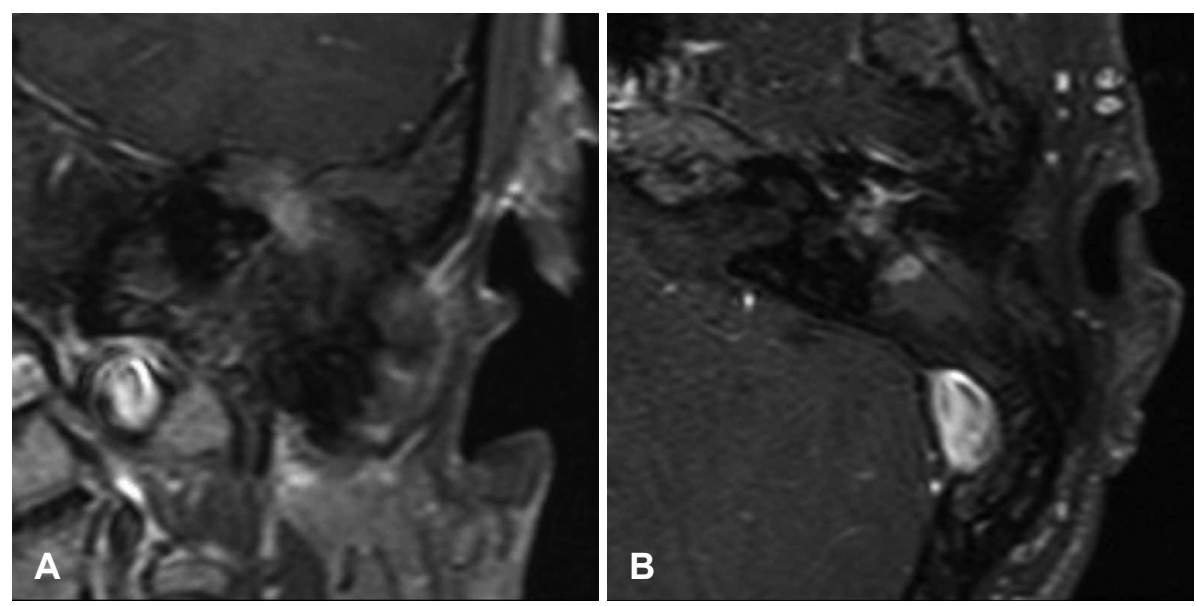

Fig. 4. Internal auditory canal MRI. Coronal view (A). Axial view of left ear (B). T1 enhanced image of the tumor showing irregular border with peripheral enhancement and heterogenous low to moderate intensity
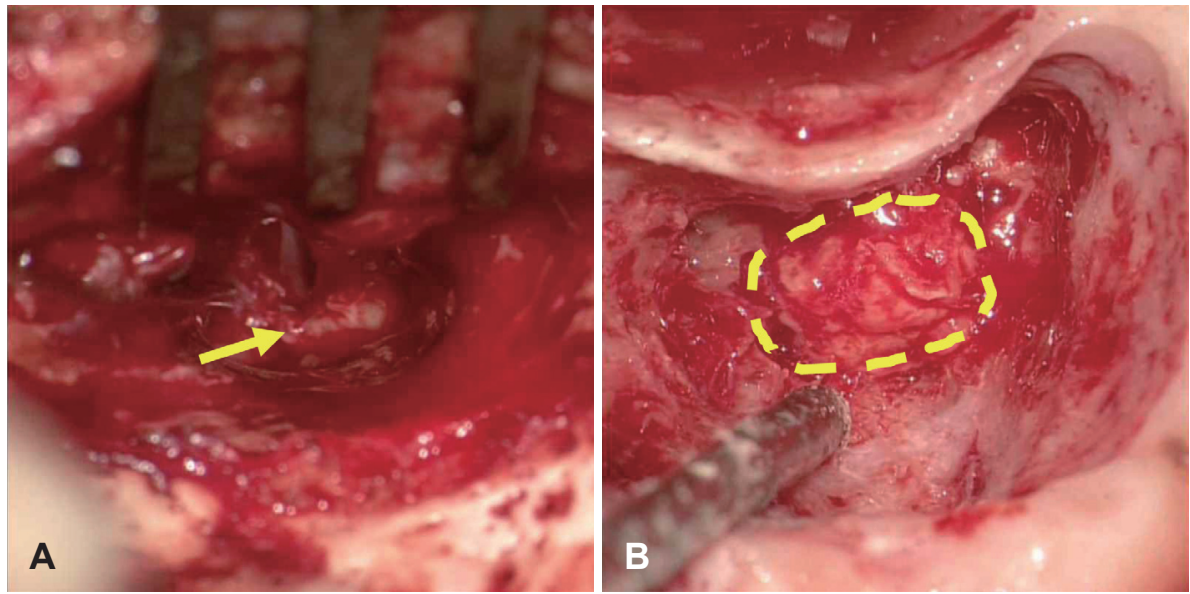
signal.

Fig. 5. The intraoperative findings: a yellowish mass occupying mesotympanum as well as tympanic membrane ( $\mathrm{A}$, arrow). The mass was seen in antrum via transmastoid approach ( $\mathrm{B}$, dotted line). The mass was successfully removed with clear margin.

비균일한 고강도 신호를 보였고 T1 강조영상에서는 불규칙하 며 변연부조영증강 및 저-중등도의 신호강도를 보이는 종괴 가 유양돌기의 함기세포와 유양돌기동 및 중이에서 관찰되 었다(Fig. 4). 고막 소견과 영상 소견을 종합하여, 콜레스테롤 육아종, 고실 내 혈관종, 선천성 진주종 등 중이 내의 종양을 의심하여 조직검사 및 종물을 제거하기 위해 시험적 고실개 방술 및 폐쇄동 유양돌기삭개술을 계획하였다.

중이의 종물이 노출되기 전까지 후이개 접근 및 유양동삭개 술의 전형적인 절차로 진행되었다. 중이를 노출시킨 후에는 노 란색을 띄는 종물이 관찰되었으며 동결절편 조직검사상 선 양화생 혹은 선종 소견을 보였다(Fig. 5A), 중이에서 기원한 것으로 생각되는 종물은 추골과 침골을 둘러싸고 있었으며 유양동의 입구까지 확장되어 있었다(Fig. 5B). 종물은 비교적 주변 골조직과 잘 박리가 되었고, 악성이 아님을 확인하였으 므로, 침골이 확인되는 유양동 입구 부위에서 종물을 일단 절제하여 추가 동결절편 및 영구조직검사를 의뢰하였다. 추 침골 관절의 상부에 경미한 골신생이 관찰되어 이로 인해 관 절의 운동성이 떨어져 있었으나 이를 제거 후 운동성이 회복되 는 것을 관찰할 수 있었다. 침골 몸통 및 단돌기의 경미한 미란
성 병변이 관찰되었으나 등골의 운동성은 유지되고 있었다. 종 물은 고막과 완전히 유착되어 박리가 되지 않았으나 주위의 골조직과는 비교적 박리가 잘 되었다. 먼저 종물로 인해 일부 미란이 관찰되는 침골을 등골로부터 분리하였다. 이후 정상 적으로 보이는 고막의 앞쪽 경계만을 남긴 후 고막의 대부분 과 일부 외이도 피부를 절제하고 추골병과 등골만을 남기고 유양돌기동(mastoid antrum)으로 나와 있는 부분의 종괴를 안면신경에 손상을 주지 않도록 조심스럽게 박리하여 제거 를 시도하였다. 중이 내의 병변에 대해서는 상고실절개술을 시 행 후 이소골과 박리된 고실 부분의 종양도 en bloc으로 절 제 가능하였다. 중이의 종양은 중이의 점막에서 기원하는 것 으로 알려져 있으나 명확한 기원 부위를 찾기는 어려워 비정 상적으로 보이는 부위는 모두 제거하는 것으로 하였다. 안면 신경은 고실 분절이 일부 노출되어 있었으나 종양의 신경 내 침범은 관찰되지 않았으나 종양과 안면신경과의 유착은 관 찰되었으며 종양 제거 후 안면신경의 색깔 변화나 부종 등이 관찰되지 않았다. 측두근막을 이용하여 고막을 재건하였으 며, 추후 이차 관찰 수술(second look operation)을 하면서 이소골 재건술을 하기 위해 미리 이개연골을 채취하여 고실의 
Fig. 6. Immunohistochemistry of the tumor which showed positive on both CD $56(\times 40)(A)$ and synaptophy$\sin (\times 40)(B)$.

Fig. 7. Microscopic findings of middle ear neuroendocrine adenoma: trabecular growth pattern composed of columnar cells $(\times 40)(A)$, showing salt-and-pepper appearance in nucleus $(\times 200)(B)$.
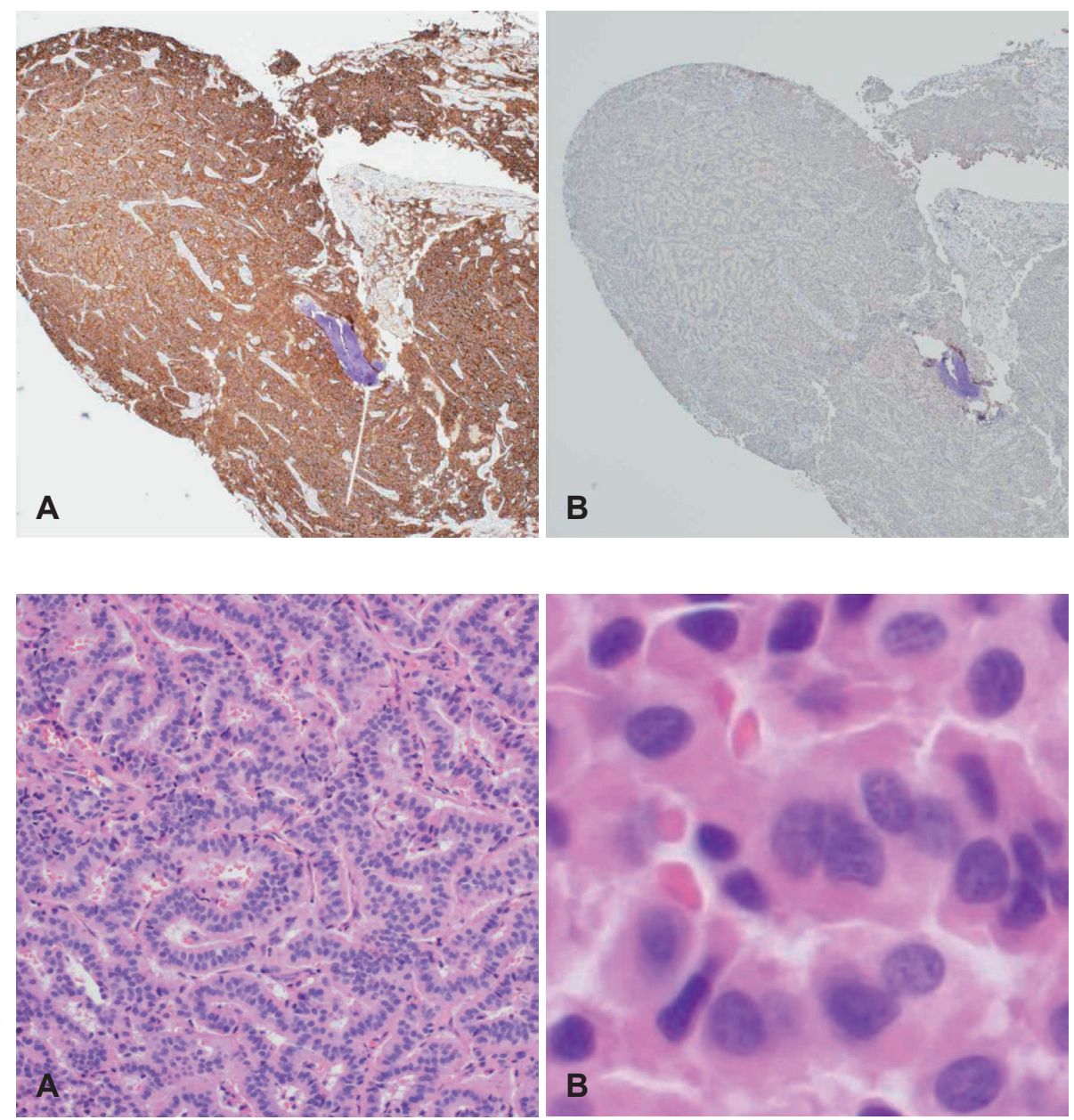

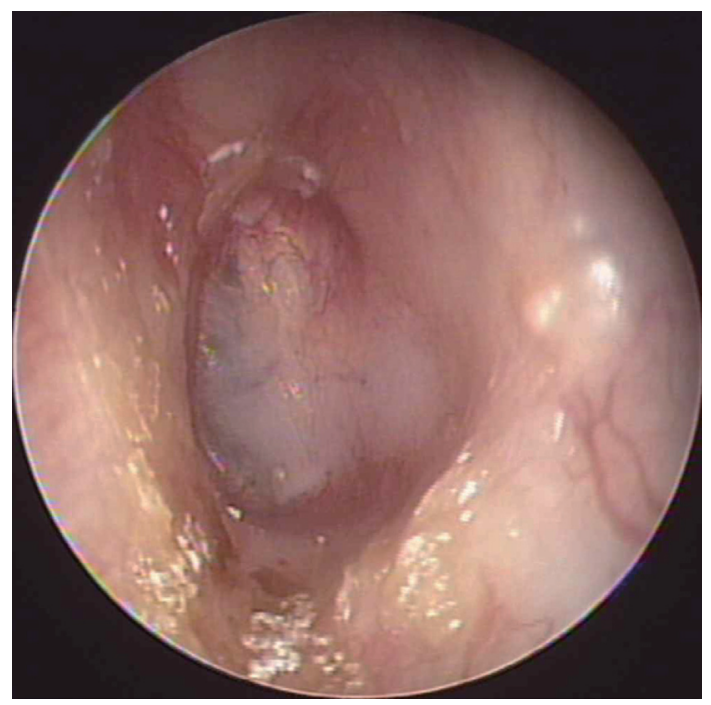

Fig. 8. A postoperative endoscopic exam: 3 months after the surgery with well-formed tympanic membrane and no sign of recurrence.

후상방을 보강한 후 수술을 종료하였다. 수술 시행 3일째에 특별한 합병증 없이 퇴원하였다.

영구조직검사에서는 주세포로 이루어진 소주형 증식양상
및 소금과 후추양상의 염색질을 보여 신경내분비성선종으로 진단되었고 면역조직화학염색상 CD56, synaptophysin에서 양성을 보이고 S-100에 대해서는 음성을 보여 선종 중에서도 신경내분비성 종양임을 뒷받침하였다(Figs. 6 and 7).

수술 3개월 후에 외래 추적관찰에서 고막 내 종물은 더 이 상 관찰되지 않았고, 순음청력검사에서 골도 $17.5 \mathrm{~dB}$ 로 골도 청력의 감소는 관찰되지 않았고, 수술 중 침골을 제거하였기 때문에 기도 청력 $66 \mathrm{~dB}$ 로 전음성 난청을 보였다(Fig. 8). 안 면마비는 House-Brackmann grade II로 수술 전과 동일하였 고, 기타 다른 합병증은 관찰되지 않았으며, 이소골 성형술 및 종물의 재발을 확인하기 위하여 약 6개월 뒤 이소골 성형 술 시행 시 이차 관찰을 계획 중이다.

\section{고 찰}

중이의 선종은 매우 드문 종양으로 1976년 Hyams와 Michaels ${ }^{1)}$ 에 의해서 처음 소개되었다. 이후 1980에 Murphy 등") 에 의해 신경선종분화(neuroendocrine differentiation)를 띄 
는 선종(adenoma), 즉 칼시노이드 종양을 보고하였는데 현 재 대부분의 저자들은 중이의 선종과 신경내분비분화선종 은 동일할 것으로 생각하고 있다. ${ }^{78)}$ 본 증례의 동결절편 조직 검사상 확인되었던 중이의 샘양화생 혹은 선종은 영구조직 검사에서 신경내분비화선종으로 확인되었다. 다만 재발하는 사례가 있어 저등급 암종으로 보아야 한다는 의견도 있으며 종양의 기원 부위를 명확하게 찾기는 어려워 비정상적으로 관찰되는 부위는 모두 제거하였다. 재발의 가능성이 있어 6 개월 후의 이소골 성형술을 겸한 이차 관찰 수술을 계획하 였다. 본 증례에서 이소골 성형술을 동시에 시행하지 않은 이 유는 상고실절개술로 상고실 벽 일부를 제거하였고 고막의 대부분 또한 종양과 함께 절제하였기 때문에 고막 착상 부위 의 일부 변화가 있을 것으로 예상되어 추후 고막의 위치가 안정화된 후 시행하기 위함이었다. 또한 이차 관찰 수술이 계 획되어 있었기 때문에 이소골 성형술을 시행하면서 고실을 개방하여 재발 유무를 확인하여도 무리가 없을 것으로 생각 되었다. 병측의 청력저하를 호소하는 중이의 선종은 국내 학 계에 보고된 바가 있지만 안면마비를 동반한 증례는 국내에 는 보고된 것이 없으며 1980년 Zahtz에 의해서 처음 보고되 었다. ${ }^{3,10)} \mathrm{Zahtz}$ 등 ${ }^{11)}$ 에 의하면 안면신경관(fallopian canal)의 골부에서 안면신경의 열개가 발생하였다고 하며 종물을 완 전히 제거 후 6개월 뒤에 안면마비는 완전히 회복되었다고 한다. 하지만 본 증례에서는 측두골 컴퓨터단층촬영에서 종 양의 안면신경 침범은 명확히 관찰되지 않았으나 수술장에 서는 안면신경의 고실 분절 원위부와 두 번째 무릎 $(2 \mathrm{nd}$ genu) 부위에서 열개가 관찰되었다. 하지만 일부에서만 이러 한 소견이 관찰되었고 종양 제거 후 안면신경의 색깔 변화나 부종이 관찰되지는 않아 처음 안면마비가 발병했을 당시 종 양의 종괴 효과에 의해 안면신경관에 미란성 병변을 유발하 였으나 스테로이드 등의 치료에 의해 호전되었을 것으로 생 각된다. 현재는 종양의 크기 증가가 미미하여 안면신경의 압 박은 없는 것으로 보였으며 추가로 안면신경 감압술은 시행 하지 않았다. 또한 이전의 완전 안면마비에서 현재는 HouseBrackmann grade II로 호전되어 추가적인 안면신경 감압술 의 효과는 적을 것으로 생각되었다. Saliba와 Evrard게 에 의 하면 $86.3 \%$ 의 환자에서 일측성 난청, $33 \%$ 에서는 이충만감 으로 내원한다. 그러나 이증상 외의 증상으로 내원하는 경우 는 흔하지 않다. ${ }^{12)}$ 영상의학적 검사로는 전산화단층촬영 및 자기공명영상을 시행하여 볼 수 있는데 전산화단층촬영에서 는 연조직의 감쇄도를 보이는 증강된 종괴를 관찰할 수 있으 며 대개는 골미란이 관찰되지 않는다. 자기공명영상의 $\mathrm{T} 1$ 강 조 영상에서는 저-중등도의 신호강도를 보이며 $\mathrm{T} 2$ 에서는 고 신호강도를, gadolinium을 주입 직후에 조영 증강되는 소견
을 보인다. 이때 감별해야 할 질환으로는 부신경절종, 신경초 종, 내림프낭 종양, 후고실 혈관종괴, 지방종 등이 있다. ${ }^{13)}$ 평 균적으로 절반 이상의 경우에서 상, 중, 하고실을 모두 침범 하며 $35 \%$ 에서 회백색을 띄며 $15 \%$ 에서 섬유화 혹은 폴립 양 상을 띄고 있다. 본 증례에서도 전형적인 양상으로 관찰되었 다. 또한 면역조직화학적 염색에서는 총 75 개의 증례에서 $44 \%$ 에 있서 chromogranin 양성을 보이고 synaptophysin에 대해 서는 20\%에서 양성을 보였다. ${ }^{7)}$ Torske와 Thompson ${ }^{8}$ 이 48명 의 환자군에서 시행한 연구에서는 chromogranin은 $87.5 \%$, synaptophysin은 $31.3 \%$ 에서 양성을 보였으며 반드시 chromogranin이나 synaptophysin에 양성을 보일 필요는 없지만 적어 도 한 가지의 신경내분비종양 표지자에 양성을 보일 시 신경내 분비종양을 강하게 시사한다고 하였다. 본 증례에서는 S-100 에 대해서는 음성을 보여 신경초종을 배제할 수 있었다. ${ }^{14)}$

중이선종의 치료로는 수술적 제거를 통한 종물의 완전절제 로서 종물이 이소골을 침범했다면 이소골도 제거하여야 한 다. 이소골이 잔존하는 경우 재발의 가능성이 있다. 방사선 치 료를 시행하였다는 소수의 증례도 보고되었으나 그 숫자가 적어 효과를 판정하기에는 무리가 있으며 수술적 절제만으로 도 완치율이 높고 재발율이 적어 방사선 치료는 대부분의 경 우에서 필요 없는 것으로 보고 있다. ${ }^{15)}$

저자들은 일측의 난청과 안면마비로 내원한 환자에서 발견 된 중이의 신경내분비성 선종 1 예를 체험하였기에 이를 문헌 고찰과 함께 보고하는 바이다.

\section{REFERENCES}

1) Hyams VJ, Michaels L. Benign adenomatous neoplasm (adenoma) of the middle ear. Clin Otolaryngol Allied Sci 1976;1(1):17-26.

2) Kwon J, Koh JW, Park SI, Jeong SH, Kim KY, Paik SI. A case of adenomatous tumor of the middle ear. Korean J OtorhinolaryngolHead Neck Surg 1991;34(6):1322-7.

3) Shin BS, Kim JR, Jeong HW, Kim EK. Two cases of middle ear adenoma with neuroendocrine differentiation (carcinoid tumor). Korean J Otorhinolaryngol-Head Neck Surg 2011;54(8):573-7.

4) Ferlito A, Devaney KO, Rinaldo A. Primary carcinoid tumor of the middle ear: a potentially metastasizing tumor. Acta Otolaryngol 2006; 126(3):228-31.

5) Gunduz M, Yamanaka N, Saito T, Kuki K, Yokoyama M, Nakamine $\mathrm{H}$. Middle ear adenoma with neuroendocrine differentiation. Auris Nasus Larynx 2000;27(1):73-6.

6) Duderstadt M, Förster C, Welkoborsky HJ, Ostertag H. Adenomatous tumors of the middle ear and temporal bone: clinical, morphological and tumor biological characteristics of challenging neoplastic lesions. Eur Arch Otorhinolaryngol 2012;269(3):823-31.

7) Saliba I, Evrard AS. Middle ear glandular neoplasms: adenoma, carcinoma or adenoma with neuroendocrine differentiation: a case series. Cases J 2009;2:6508.

8) Torske KR, Thompson LD. Adenoma versus carcinoid tumor of the middle ear: a study of 48 cases and review of the literature. Mod Pathol 2002;15(5):543-55.

9) Murphy GF, Pilch BZ, Dickersin GR, Goodman ML, Nadol JB Jr. Carcinoid tumor of the middle ear. Am J Clin Pathol 1980;73(6): 
816-23.

10) Shim MJ, Song CI, Yoon TH. A case of middle ear adenoma. Korean J Audiol 2012;16(1):27-30.

11) Zahtz GD, Zielinski B, Abramson AL. Benign adenoma of the middle ear cavity causing facial paralysis. Otolaryngol Head Neck Surg 1981; 89(4):624-8.

12) Latif MA, Madders DJ, Barton RP, Shaw PA. Carcinoid tumour of the middle ear associated with systemic symptoms. J Laryngol Otol 1987; 101(5):480-6
13) Zan E, Limb CJ, Koehler JF, Yousem DM. Middle ear adenoma: a challenging diagnosis. AJNR Am J Neuroradiol 2009;30(8):1602-3.

14) Nakajima $T$, Watanabe $S$, Sato $Y$, Kameya $T$, Hirota $T$, Shimosato $Y$. An immunoperoxidase study of S-100 protein distribution in normal and neoplastic tissues. Am J Surg Pathol 1982;6(8):715-27.

15) Hasan Z, McGinness S, Gunaratne DA, Coleman H, Varikatt W, da Cruz M. Neuroendocrine adenoma of the middle ear: a rare histopathological diagnosis. Case Rep Otolaryngol 2016;2016:9834750. 